\title{
Artificial Intelligence Librarian as Promotion of IAIN Lhokseumawe Library in the Revolutionary Era 4.0
}

\author{
Aida Hayani ${ }^{1}$, Evi Aprilia Sari², Sukiman ${ }^{2}$ \\ ${ }^{1,2}$ Doctoral Student of Islamic Education Yogyakarta, Yogyakarta, Indonesia \\ Universitas Negeri Malang, Malang, Indonesia. \\ Lecture of Islamic Education Yogyakarta, Yogyakarta, Indonesia \\ Email: aidaalmahira@yahoo.com
}

\begin{abstract}
Era 4.0. is a revolution in the industrial world, in the era referred to as the phenomenon distruptive innovation. In the industrial era 4.0, the emphasis lies on the digital economy pattern, artificial intelligence (artificial intelligence) big data, robotics, and automation. The impact of the industrial era 4.0 influential in various fields of work are no exception librarians. Librarian is someone who has the ability and expertise librarianship the librarians in charge to prepare themselves to face the era that is the way to equip themselves with information technology and analytical capabilities of the library so that airport users effective. Then by applying a librarian AI (artificial intelligence) to guide users in using the integrated library information. The presence of librarians AI (artificial intelligence) at IAIN Lhokseumawe made of evidence that has entered the era of disruption 4.0 will be the college library promotion strategy
\end{abstract}

\section{Keywords-Artifical Intellegence, Revolution, Library}

\section{INTRODUCTION}

Universities in Indonesia are required to improve the quality through the process of education in the college include: education (teaching), research (research), and services (services). To be effective universities need to be supported by several supporting activities related, such as a library. The library is a university supporting unit which is extremely important. Even the library is often referred to as the heart of the college. Through this college library compiled knowledge can be fully utilized as an asset repository [1] of knowledge that is very valuable and valued.

Due to function library is one place that holds a collection of civilization. Changing times and globalization has positive impacts on the flow of information. In order not outdated and this nation become more intelligent, inevitably, the library as a repository of knowledge, resources should be managed by a professional to be able to take part in the international world. In that regard, the librarian has a very important position in realizing international university library. Therefore, librarians must change their mindset from providing information (information provider) to have the ability and expertise in accessing information (information access provider). As an absolute requirement that must be met is to master information and communication technology (ICT) as well as the mastery of a foreign language. Library functions for the university / institute / university sangatl vital, such as the heart in the human body. To build a library that is able to work together with universities and academic community, in this case the necessary human resources professional librarians, who have a high work ethic, honest, dedicated, loyal and have the willingness and ability to evolve and continue to gain knowledge for life.

Creativity and innovation [2] is required to perform a transformation in both the service and the availability of information in the library. Adjustment of information and communication technologies can have an impact on library use effectively and efficiently. In other words, information and communication technology can support the process of management and services by librarians to users. The role of librarians certainly must to afford berkolabor prangkat ation with the media and information technology provided by the library. But in practice in Lhokseumawe IAIN not all librarians have the ability to access freely to manage and provide superior service to pangguna. It takes a qualified librarian competence in the field of information and communication technology. Librarian competencies [3] needed on the understanding more about adjusment and compliance information from the user's needs. In the era of information technology disruptsi or known as the industrial revolution 4.0 requires librarians to be able to collaborate and communicate ririskiky good that has an automated into a system.

The presence of information technology and the Internet can replace humans on the job or activity parktik always apply continuous or monotonous. In the library world of work that can be replaced by information technology include the management, service, crawling of and preservation of library materials digitally. It explains and proves that the phenomenon entered the era of disruption. A librarian profession is taken into account for the continuation of the existence of in libary Performance of a librarian needs to be considered on the competence or capabilities and adapt to the development of information technology today [4]. Librarians have a duty and responsibility to each services, includes services circulation, reference, management, procurement collection, reservoir and part technician (audit). Work that requires focus and precision of each service is sometimes encountered a problem that can hinder the performance of a librarian. For example, there are users who have never been 
or do not understand or comprehend information retrieval and data or information needed will certainly ask the clerk. Effective performance of librarians in libraries to be operational time increases and easily unfocused or tired. For example, there are users who have never been or do not understand or comprehend information retrieval and data or information needed will certainly ask the clerk. The effectiveness performance of librarians in libraries to be operational time increases and easily unfocused or tired. For example, there are users who have never been or do not understand or comprehend information retrieval and data or information needed will certainly ask the clerk. Performance of librarians in libraries operational time increases and easily unfocused or tired.

A librarian may not necessarily have the competence or the ability of library management [4] and service complex or multitasking. They need innovation that can help librarians in terms of communication. With information and communication technologies both applications and platforms have been red Librarian can do a collaboration with information technology media now known by the term synthetic Intelligence [3] or artificial intelligence [5], [6] is integrated with the system, the general technical AI systems will automatically be read images, sound or desire someone about something. The concept is on offer on Artificial Intelligence [5]-[8] in this paper an idea that has never been created or published by a journal.

One technique that is becoming popular is Artificial Intelligence[9], [10] is becoming famous for its many types of applications. This is what can now be encountered every day like on the iPhone and voice recognition or voice recognition on Android cell phones. With together the term Artificial Intelligence [11][12], Machine Learning [13], Neural Networks [14], [15], and Deep Learning [16], [17] people are confused with these terms.

Utilization of artificial intelligence can be a college library strategy to promote the services and facilities provided to the user. In addition, artificial intelligence is able to maintain the existence and entertainment in the college library monotony of the material or the library materials only. Artificial intelligence is one part of computer science that studies how to build machinesor computers can do work that humans would rather do even betterdone. What Librarian can easily focus and airport users in accordance with the groove and the policy of the library. While artificial intelligence into cyberspace librarian partner in providing one-stop services to the user. Collaboration undertaken will provide an exciting experience for the user to show the sophistication of librarians who are able to read and translate the information needs of users in accordance with the chosen specialist subject.

\section{METHODOLOGY}

This study uses a naturalistic qualitative approach and is implemented for approximately 4 months starting from September until Desember 2019, in the librarian of IAIN Lhokseumawe. This study involves some research subjects from Chairman of libary that university, students, lecturers, and graduates. The determination of research subjects is done by purposive and snowball sampling, meaning the informant will increase until the information obtained satisfactorily or cannot increase more or saturated (redundancy). This research object is the development of the artificall integelince of librarian. This research is conducted with several steps consisting of data collection, data reduction through data correction, data encoding, and the true instrument is the researcher itself (human per instrument). The researchers perform direct observations and in-depth interviews on the development of the Artifical Intellegansi librarian begin from the formulation of graduate profiles, the preparation of learning achievement, the field of review and cstructure. Data obtained through observation of participation, researchers do the systematic observation and recording to the intermitters studied in the interview being carried out freely. Documents relating to this study were artificial documentation, manuscript associated with the Role of Artifical Intelligence Librarian as Promotion of IAIN Lhokseumawe Library in the Revolutionary Era 4.0, in analyzing data, the researcher uses inductive models, namely data collected then analyzed at four compounds namely data collection, data reduction, data display and withdrawal conclusions. In each component interacting and forming a cycle. Data obtained is certainly given the ground to ensure the validity of data. The level of trust the results of the research is taken in the fulfillment of credibility criteria or internal validity, translatability or external validity, dependability or reliability, and confirmability or objectivity.

\section{FINDING AND DISCUSSION}

\section{The paradigama of libraries in College}

College library is one of the libraries that are often discussed on the collection or library materials that are exempted by any number to clasification subject header. College library became an integral part of the facilities and infrastructure provided by agencies or institutions in supporting the goals of Tri Dharma (Fatmawati, 2018). College library has a very important role in meeting the information needs of its users. The information provided must be managed using information and communication technology devices.

College libraries to be responsible listed in Law No. 43, 2007 on article 24, paragraph 3 that the college library develop library services based on information technology and communications. Explanation of the laws became the starting point of the library paradigm shift from conventional ones to be modern, or so-called digital. The pattern of activity and use of information technology today that affect the library described as follows:

1. Libraries are no longer build print collection and cataloging conventionally but has focused on the resources and digital services by using information and communication technology devices. The goal is to be accessed and retrieved (retrieval information) without the barriers of distance and time.

2. The library has a flexible ability in disseminating information, manipulate the software according to the needs of both internal and external parties virtually with the aim to collaborate, simplify management and work in an institution. 
3. Librarian have a view or perspective has changed roles and responsibilities in a creative and innovative. We recommend that librarians were able to take a chance and use of information technology in the library as the abilitycompetence of quality that add value to the parent institutions, stakeholders, users and the competitors.

4. Libraries would require the capability or expertise both resources, services and digital physically software.

Disruption is an innovation that willreplaceall. The disruption replaced the old technology. completely physical with digital technology that produces something completely new and more efficient and more useful mentions various the concept in an era of disruption. This starts with automation, artificial intelligence, a concept that aims to extends the benefits of connected internet connectivity constantly internet of things [18], machine learning[19], as well as advanced technology.

The impact of the industrial revolution changes was very fast, fundamental, and even by ruffling old order patterns to create a new order. There is another derivative concept of concern to us, one example is virtual reality. Related to its presence in virtual reality technology, libraries can have a more interesting and recognizable library collection by society at large. Through virtual reality [20], we can too develop their own through applications that are often available regularly free on the internet. Technology in virtual reality has 4 (four) basic characteristics, namely: immersion, imagination, interactivity, and multisensory. The concept of virtual reality [21] explained that “... is a comprehensive integration technology, involved with computer graphics, sensor technology, human-computer interaction techniques, artificial intelligence, and other fields ".

The librarian must have a selling point by enhancing the image and institutional visibility to strengthen the library's existence. Thus, the library through its librarian must creating innovative ways and breakthroughs, so that they can become the main goal for a librarian in seeking references to knowledge. Innovation must always be done so that libraries are not abandoned by the librarian. The problem is what kind of innovation is conducted?. Innovation is an opportunity to improve deepl improve service quality and library performance. Librarian college as the main element that brings the library in the future.

The attention to interests the user by looking at the needs as well satisfaction with service is a key factor for organizational success in achieving goals amid a climate of increasingly competitive good competition for similar organizations and organizations engaged in the field the same but looking for profit. A the librarian must understand the point of view users, that users are not just use the services provided however also, fulfill various emotional elements, and affections such as lifestyle, identity, adventure, love and friendship, peace as well trust.

\section{Paradigma of Artifical Intelligence}

Artificial Intelligence defined as intelligence denoted by an artificial entity. Such a system is generally considered a computer [8], [22], [23]. Intelligence is created and put into a machine (computer) in order can do the job as it can be done, human. Artificial Intelligence (or AI) is defined as demonstrated intelligence by an artificial entity. Artificial Intelligence [24] is a branch of science that deals with using machines to solve complex problems more humanly. This is usually done by following/imitating the characteristics and thinking analogies of human intelligence and applying them as algorithms known to computers. A more or less flexible and efficient approach can be taken depending on the needs, which influence how artificial intelligence behaves. AI is usually associated with Computer Science but is also closely related to other fields such as Mathematics, Psychology, Observation, Biology, Philosophy, and others. The ability to combine knowledge from all of these fields will ultimately benefit progress in creating an artificial intelligence.

Despite realizing that artificial intelligence can so is a threat to humans, but humans still developing what is called with artificial intelligence. Humans are still trying to develop/get something (technology) that is new, who can think like humans. This thing happened because there is dissatisfaction in humans, humans want to get something in a more way easy. There are limitations, after all in humans, like the only human brain able to think with a frequency of approximately $100 \mathrm{~Hz}$ and because humans have a sense of fatigue. Compare with today's computers capable of processing data with a frequency of $4 \mathrm{GHz}$. Computers also don't have to feel tired even though you have to process the same data over.

\section{Formulation of the Indonesian Qualification Framework}

The accuracy and agility of a library can be seen from the performance of librarians who support all programs and good service. From the above presentation explained that as the development time and as evidence of the disruption entered the era of 4.0 which is the utilization of information technology tools in various fields one of which is the library. a paradigm shift not not come suddenly but it has been estimated by experts in information and communication much earlier. Preparation is also done by Kemenristekdikti policy pengintegrasisan electronic information resources to improve the quality of higher education in Indonesia.

There are regulations that explains the obligation of universities to the mandate of Article 85 of PP 24 of 2014 concerning the library as a learning resource center and support the educational goals domiciled in college. Mandate Article 85 Regulation 24 of 2014 contains that each college is obliged to:

a) Organizing the library that meets national standards library with attention to national education standards;

b) Has a collection of both the number of titles and number of copies, which is sufficient to support the implementation of education, research, and community service;

c) Technology base library services develop information and communication; and d) Allocate funds to develop peprustakaan accordance with the provisions of legislation in order to comply with 
national standards and national standards library. (Naim, 2018)

The law regulations concerning good library of Act No. 43 of 2007 and Decree No. 24 of 2014 government or require the library to be able to develop services and infrastructurebased library of information and communication technology with national standards are applicable libraries and education. Libraries today have changed very visible both service and facilities provided. The development library has now entered the era of disruption, which have an impact on services, availability of information and thought patterns that can be out of the box. Innovation continues to use the integrated information technology through the application or integrated search platform that is online in the library.

Artifiacial intelligenced libraries [25] can be applied to websites using live chat or web semantic base. However, innovations in the field of information technology is not up to the application website, now can use intelligence artifiacial actively in communication with individuals or robots on the same monitor as humans. The two-way communication and adjustments required by robot users of IT in the monitor. Graphically very interesting there is a button that allows users to interact. The monitor used is a large-sized monitor instead of a computer. Libraries can collaborate and cooperate with relevant parties according to their field experts. Implementation artifiacial intelligencedi library obstacles encountered thus has good human resources, costs and policies contained in a in institution. But artificial intelligence has the advantage to described in McKinsey research in application are: 1) to reduce operating costs; 2) Information boost revenue; 3) mengoprtimalkan use one set of product promotion agencies accurately and improve services to users.

Marketing is an important part of the organization. Manufacturing companies, service companies, and non-profit companies must do marketing to achieve their goals. Libraries as a non-profit organization do marketing to attract users to use library services. Especially with the development of internet technology, the easier it is to find information via the internet without the need to come to the library. So that we need more serious efforts in marketing the library.

Artifiacial intelligence [26] can provide a different experience of innovation ever applied in the college library. This implementation is not to replace the role of the librarian but helps optimal performance and integrated with a system in the library. Artifiacial intelligence [27] model of the latest innovations will not yet be implemented by all library universities in Indonesia. However, its application can be started from a network of cooperation with various parties, including the holders of responsibility. Concept or careful thought will artifiacial the intelligence in order to maintain the existence and promotion strategy of the college library to the general public. Such as in UIN Sunan Kalijaga

In that figure 1 that the librarians give provide service to visitor, its so deference in IAIN Lhokseumawe, when the visitor go in the library the will do it too but the facility of the library inadequate than UIN Sunan Kalijaga.

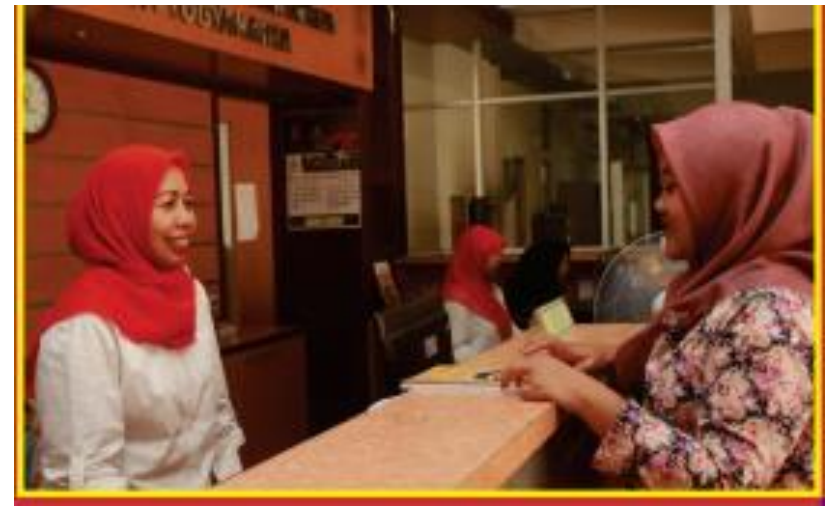

Fig. 1. The librarians give provide service to visitors

Through utilization of information technology systems in libraries, librarians required to be able to develop and provide appropriate services with the needs of users. Library has undergone several evolutions in its development. If originally the library focused on library collections and services, now it has shifted to added value. Thus, the development of libraries at the next stage is very possible and can be created. This is necessary to adapt to the development of users and developments in information technology. The hope is that various adjustments can make libraries more valuable and have a greater impact on the world of education. The existence of artificial intelligence [28], big data, internet of things [29], cloud-based services, and smart tools [30], as a feature of the Industrial Revolution 4.0 will make many changes in the world of education. As a result, library managers in various parts of the world are guessing the next breakthrough that must be made There are some obstacles encountered in this case is as follows:

\section{a. Constraints of the}

These constraints are from the library. Neither the library nor pustakawaannya own. Such constraints such as the lack of knowledge pustakaawan perpustakawan IAIN Lhokseumawe on science and librarian marketing and promotion, lack of adequate and sustainable funding for promotional activities IAIN Lhokseumawe library, the library must have a lack of awareness of the services and services to attention of the visitior comes to the library

\section{b. Constraints on the outside}

These constraints come from outside the library just as the lack of desire of the government of Aceh to Lhokseumawe IAIN help libraries in terms of funding, lack of cooperation with instiasi library like other universities.

Library IAIN Lhokseumawe undertake to overcome the above problems can perform some of the ways between the anticipate constraints from within that provided specialist training for librarians in the field marketing and promotion of libraries, provide counseling and seminars that libraries today is not just a warehouse of books but as the repository of a place to anticipate and raise awareness of librarians that the library should have a service and services to attract the attention of the libararian. Meanwhile, to overcome obstacles on the outside that the city government should be more serious Lhokseumawe to promote the library by helping provide budget sufficient and sustained so that promotional 
activities uninterrupted library and collaborate with other libraries such as universities.

Promotion is one of the mechanisms of persuasive communication in marketing in order for goods or services offered can be sold to consumers. While promotions are generally delivering the right message to the right person. From the above presentation it can be concluded that the promotion is a marketing kegiaitan persuasively that provide information about the goods or services to users with effective communication. Promotion is done to provide information that is important to know users better and able to attract users on a sense keingantahuan obyek. The strategy library promotion is establishing a communication with librarian to make use of science communication in all promotions to the user. Promotion can be done by building cooperation with third parties to provide services such as fulfillment of various user to need especially in the service promotion. In a promotional strategy in the scope of the library includes setting goals or priorities a plan of work. There are some promotional strategies that need to be done in the approaches to the analysis of the factors that influence it, as follows: 1) Environmental factors, taking into account population and rules or policies that are important to determine the effect inflicted on an organization, and the development of technology information should be considered juga. 2) market factor (academicians), need to know the size of the market, the rate of population growth, stage of development of both technology and user behavioral pattern libraries that can be used as an opportunity to be uses. Media which is used in a promotion is a tool that is used as a promotional tool in the library. There are several forms of media and library prmosi, among other things: 1) The print media; 2) The electronic media; 3 ) non-mass media; 4) Media meetings.

The focus of this study, using electronic media promotions are packed with interesting use of information and communication technologies are evolving that is social media. With the use of social media and intenet will be more easy for promote library and provide information related to new facilities or services featured. The importance of the role of libraries in the promotion of the facility or service to provide knowledge to the user regarding the assets and advantages are valuable and important in an agency. Libraries certainly set to be a part of maintenance culture of the nation and provide information that aims to meet the needs of library users.

\section{CONCLUSION}

College library is one of the libraries that are often discussed on the collection or library materials that are exempted by any number classification subject header. These constraints are from the library. Neither the library nor the uses own. Such constraints such as the lack of knowledge user in IAIN Lhokseumawe on science and librarian marketing and promotion, lack of adequate and sustainable funding for promotional activities IAIN Lhokseumawe library, the library must have a lack of awareness of the services and services to attract attention of the librarian. These constraints come from outside the library just as the lack of desire of the government of Aceh to Lhokseumawe
IAIN help libraries in terms of funding, lack of cooperation with instiasi library like other universities.

\section{REFERENCES}

[1] M. Danny, F. Madelaine, C. Huriviades, and S. Dalys, "Digital Institutional Repositories, Component of Open Science to Disseminate Scientific Publications: Case Repository UTP-Ridda2," in 2019 7th International Engineering, Sciences and Technology Conference (IESTEC), 2019, pp. 653-658.

[2] B. Meunier, "Library Technology and Innovation As A Force for Public Good A Case Study from UCL Library Services," IEEE 5th Int. Symp. Emerg. Trends Technol. Libr. Inf. Serv. ETTLIS 2018, pp. 159$165,2018$.

[3] J. Ronczka and L. McKenzie, "Industry Engagement with Synthetic Intelligence: To Drive Sustainable Human-Technology 'Ecosystem Quality' (EQ)," in 2018 5th Asia-Pacific World Congress on Computer Science and Engineering (APWC on CSE), 2018, pp. 164-171.

[4] R. Patnaik and M. K. Mishra, "Role of Content Management Software (CMS) in libraries for information dissemination," in 2015 4th International Symposium on Emerging Trends and Technologies in Libraries and Information Services, 2015, pp. 117-121.

[5] K. Hafeez and S. Khan, "Risk management analysis with the help of lightning strike mapping around $500 \mathrm{k}-\mathrm{v}$ grid station using artificial intelligence technique," in 2012 International Conference of Robotics and Artificial Intelligence, 2012, pp. 165-168.

[6] Liu Xian, "Artificial intelligence and modern sports education technology," in 2010 International Conference on Artificial Intelligence and Education (ICAIE), 2010, pp. 772-776.

[7] Y. Liu and P. Tang, "The Prospect for the Application of the Surgical Navigation System Based on Artificial Intelligence and Augmented Reality," in 2018 IEEE International Conference on Artificial Intelligence and Virtual Reality (AIVR), 2018, pp. 244-246.

[8] S. Garichev and A. Vedyakhin, "Conception and Development Program of National Technology Initiative Center for Artificial Intelligence at MIPT," in 2018 International Conference on Artificial Intelligence Applications and Innovations (IC-AIAI), 2018, pp. 1-3.

[9] Y. Liu and P. Tang, "The prospect for the application of the surgical navigation system based on artificial intelligence and augmented reality," in Proceedings - 2018 IEEE International Conference on Artificial Intelligence and Virtual Reality, AIVR 2018, 2019, pp. 244246 .

[10] X. Liu, "Artificial intelligence and modern sports education technology," in Proceedings - 2010 International Conference on Artificial Intelligence and Education, ICAIE 2010, 2010, pp. 772-776.

[11] L. L. Abeysekara and H. Abdi, "Short Paper: Neuromorphic Chip Embedded Electronic Systems to Expand Artificial Intelligence," in 2019 Second International Conference on Artificial Intelligence for Industries (AI4I), 2019, pp. 119-121.

[12] U. Arsenijevic and M. Jovic, "Artificial Intelligence Marketing: Chatbots," in 2019 International Conference on Artificial Intelligence: Applications and Innovations (IC-AIAI), 2019, pp. 19-193.

[13] K. Pahwa and N. Agarwal, "Stock Market Analysis using Supervised Machine Learning," in 2019 International Conference on Machine Learning, Big Data, Cloud and Parallel Computing (COMITCon), 2019, pp. 197-200.

[14] Y. Chu, J. Fei, and S. Hou, “Adaptive Global Sliding-Mode Control for Dynamic Systems Using Double Hidden Layer Recurrent Neural Network Structure," IEEE Trans. Neural Networks Learn. Syst., vol. 31, no. 4, pp. 1297-1309, Apr. 2020. 
[15] M. Kobayashi, "Noise Robust Projection Rule for Hyperbolic Hopfield Neural Networks,” IEEE Trans. Neural Networks Learn. Syst., vol. 31, no. 1, pp. 352-356, Jan. 2020.

[16] H. Tang, H. Liu, W. Xiao, and N. Sebe, "When Dictionary Learning Meets Deep Learning: Deep Dictionary Learning and Coding Network for Image Recognition With Limited Data," IEEE Trans. Neural Networks Learn. Syst., pp. 1-13, 2020.

[17] S. Roy et al., "Deep Learning for Classification and Localization of COVID-19 Markers in Point-of-Care Lung Ultrasound," IEEE Trans. Med. Imaging, vol. 39, no. 8, pp. 2676-2687, Aug. 2020.

[18] C. Lee and A. Fumagalli, "Internet of Things Security - Multilayered Method For End to End Data Communications Over Cellular Networks," in 2019 IEEE 5th World Forum on Internet of Things (WFIoT), 2019, pp. 24-28.

[19] H. I. Bulbul and O. Unsal, "Comparison of Classification Techniques used in Machine Learning as Applied on Vocational Guidance Data," in 2011 10th International Conference on Machine Learning and Applications and Workshops, 2011, vol. 2, pp. 298-301.

[20] C. Matthes et al., "The Collaborative Virtual Reality Neurorobotics Lab," in 2019 IEEE Conference on Virtual Reality and 3D User Interfaces (VR), 2019, pp. 1671-1674.

[21] C. Oikonomou, A. Lioret, M. Santorineos, and S. Zoi, "Experimentation with the human body in virtual reality space: Body, bacteria, life-cycle," in 2017 9th International Conference on Virtual Worlds and Games for Serious Applications (VS-Games), 2017, pp. 185-186.

[22] Y.-J. Lin et al., "Artificial Intelligence of Things Wearable System for Cardiac Disease Detection," in 2019 IEEE International Conference on Artificial Intelligence Circuits and Systems (AICAS), 2019, pp. 67-70.

[23] J. Wang, L. Fang, and X. Zhuang, "Study and Application of Stock Robot Kaburobo Based on Artificial Intelligence," in 2009
International Joint Conference on Artificial Intelligence, 2009, pp. 260-262.

[24] Z. Zhang, S. Xu, and H. Yan, "Preliminary Study on Application of Artificial Intelligence Technology in Electrical Automation Control," in 2020 International Conference on Computer Information and Big Data Applications (CIBDA), 2020, pp. 128-131.

[25] B. Wang, Y. Qin, and Q. Huang, "The Prospective of Library Spurred by Artificial Inteligence-China Survey," in 2020 3rd International Conference on Advanced Electronic Materials, Computers and Software Engineering (AEMCSE), 2020, pp. 175-179.

[26] Abhivardhan, "The Perspective of Dimensional Perpetuity for Artificial Intelligence: A Model on Socio-Legal and Political Evolution as a Challenge to Entrepreneurial Ethics," in 2020 2nd World Symposium on Artificial Intelligence (WSAI), 2020, no. 2019, pp. 6972 .

[27] Z. Aung, I. S. Mikhaylov, and Y. T. Aung, "Artificial Intelligence Methods Application in Oil Industry," in 2020 IEEE Conference of Russian Young Researchers in Electrical and Electronic Engineering (EIConRus), 2020, pp. 563-567.

[28] M. Li, Z. Yang, J. Zhong, L. He, and Y. Teng, "Research on Network Attack and Defense Based on Artificial Intelligence Technology," Proc. 2020 IEEE 4th Inf. Technol. Networking, Electron. Autom. Control Conf. ITNEC 2020, vol. 3, no. Itoec, pp. 2532-2534, 2020.

[29] F. Alkhabbas, R. Spalazzese, and P. Davidsson, "Architecting Emergent Configurations in the Internet of Things," in 2017 IEEE International Conference on Software Architecture (ICSA), 2017, pp. 221-224.

[30] K. Zhu, G. Li, and Y. Zhang, "Big Data Oriented Smart Tool Condition Monitoring System,” IEEE Trans. Ind. Informatics, vol. 16, no. 6, pp. 4007-4016, Jun. 2020. 